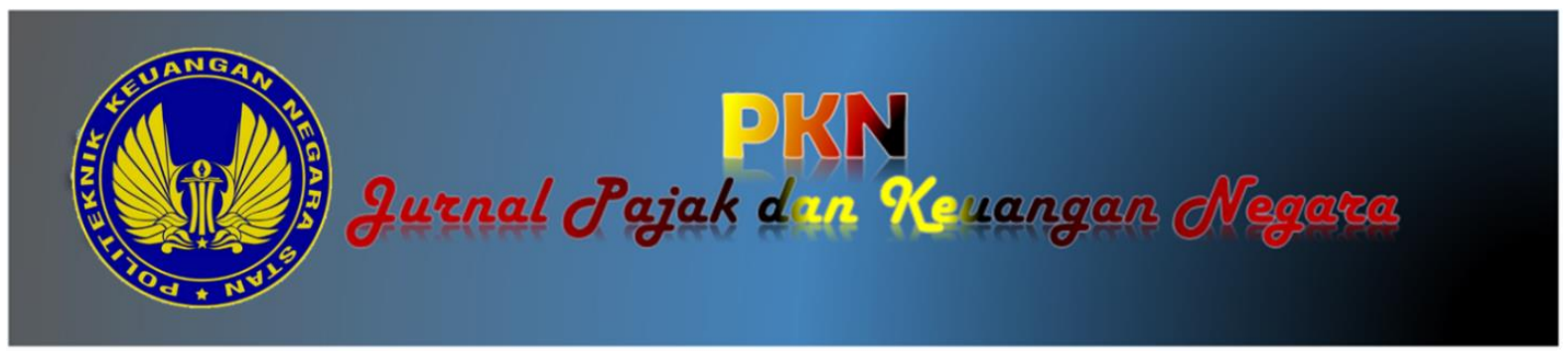

\title{
DETERMINAN FAKTOR-FAKTOR YANG MEMPENGARUHI KEPATUHAN PAJAK BENDAHARA DANA BANTUAN OPERASIONAL SEKOLAH
}

\author{
Asqolani \\ Politeknik Keuangan Negara STAN \\ Sopian \\ Politeknik Keuangan Negara STAN
}

Alamat Korespondensi: asqolani@pknstan.ac.id

\section{INFORMASI ARTIKEL \\ Diterima Pertama \\ [01 08 2021] \\ Dinyatakan Diterima \\ [24 08 2021]}

KATA KUNCI:

Kepatuhan pajak, pelayanan, pemeriksaan, sanksi, Bendahara Operasional Sekolah (BOS), PLS-SEM

\section{KLASIFIKASI JEL:}

[Untuk klasifikasi keywords menggunakan standard JEL codes yang dapat diakses pada http://www.aeaweb.org/jel/guide/jel.php]

\section{ABSTRACT}

Tax non-compliance in the management of School Operational Assistance Funds (BOS) can lead to a reduction in tax revenues and increase the potential for tax penalties. The purpose of the study was to examine whether the tax services, tax sanctions, and tax audit affect the tax compliance of the manager of BOS as exogenous variables. The data comes from a survey of 87 respondents, the manager of the School Operational Fund (BOS) in the city of South Tangerang in 2019. This sample was selected to represent the largest recipient of BOS funds in Banten Province. This research uses the Likert scale instrument then analyzed using PLS-SEM. The result shows that taxpayer services, tax sanctions, and tax audit have a significant influence on the tax compliance of the manager of the School Operational Fund (BOS). The results of this study can be used by the Directorate General of Taxes in identifying what factors can be maximized in improving taxpayer compliance.

\section{ABSTRAK}

Ketidakpatuhan perpajakan dalam pengelolaan Dana Operasional Sekolah (BOS) dapat menyebabkan pengurangan penerimaan pajak dan meningkatkan potensi sanksi administrasi. Tujuan dari penelitian ini adalah untuk menentukan pelayanan pajak, sanksi pajak, dan pemeriksaan pajak menjadi variabel endogen berdampak signifikan terhadap kepatuhan perpajakan bendahara BOS sebagai variabel eksogen. Data berasal dari survei terhadap 87 responden yaitu bendahara Dana Operasional Sekolah (BOS) di kota Tangerang Selatan pada tahun 2019. Sampel ini dipilih mewakili penerima dana BOS terbesar di Provinsi Banten. Instrumen penelitian ini menggunakan skala Likert kemudian dianalisis dengan menggunakan PLS-SEM. Hasil penelitian menunjukkan bahwa pelayanan wajib pajak, sanksi pajak, dan pemeriksa pajak memiliki pengaruh signifikan terhadap kepatuhan bendahara Dana Operasional Sekolah (BOS). Hasil penelitian ini dapat digunakan oleh Direktorat Jenderal Pajak dalam mengidentifikasi faktor apa saja yang dapat dimaksimalkan dalam meningkatkan kepatuhan Wajib Pajak. 


\section{PENDAHULUAN}

Bantuan Operasional Sekolah Reguler yang selanjutnya disingkat BOS Reguler adalah program Pemerintah Pusat untuk penyediaan pendanaan biaya operasi personalia dan non personalia bagi sekolah yang bersumber dari dana alokasi khusus non fisik (Permendikbud, 2019). BOS Reguler bertujuan untuk membantu biaya operasional penyelenggaraan pendidikan di Sekolah. Latar belakang dana Bantuan Operasional Sekolah adalah untuk meningkatkan akses dan mutu pendidikan sebagai salah satu prioritas pembangunan nasional. Melalui pengalokasian dana bantuan operasional sekolah reguler, diharapkan dapat mendorong pemerintah daerah dalam menyelenggarakan pendidikan bagi masyarakat.

Anggaran dana BOS dalam APBN tahun 2021 direncanakan sebesar Rp58,59 Triliun dan setiap tahun terus meningkat. BOS Reguler dikelola oleh Sekolah dengan menerapkan Manajemen Berbasis Sekolah (MBS), yang memberikan kebebasan dalam perencanaan, pengelolaan, dan pengawasan program yang disesuaikan dengan kondisi dan kebutuhan Sekolah.

Gambar 1

Postur Anggaran Pendidikan TA 2021

\begin{tabular}{|c|c|c|c|c|}
\hline \multirow{8}{*}{$\begin{array}{c}\text { DAK } \\
\text { NON } \\
\text { FISIK } \\
\text { Rp } \\
116, \\
7 \\
\text { Triliu } \\
n\end{array}$} & \multirow{3}{*}{$\begin{array}{l}\text { Bantuan } \\
\text { Operasion } \\
\text { al }\end{array}$} & BOS & 53,4 & $\mathrm{~T}$ \\
\hline & & BOP PAUD & 4,01 & $\mathrm{~T}$ \\
\hline & & $\begin{array}{l}\text { BOP } \\
\text { Kesertaraan }\end{array}$ & 1,19 & $\mathrm{~T}$ \\
\hline & \multirow{3}{*}{ Tunjangan } & $\begin{array}{l}\text { Tunjangan } \\
\text { Profesi } \\
\text { PNSD }\end{array}$ & 55,3 & $\mathrm{~T}$ \\
\hline & & $\begin{array}{l}\text { Tunjangan } \\
\text { Khusus } \\
\text { PNSD }\end{array}$ & 1,95 & $\mathrm{~T}$ \\
\hline & & Tamsil Guru & $\begin{array}{c}454, \\
2\end{array}$ & M \\
\hline & \multicolumn{2}{|c|}{ BOP Museum dan TB } & $\begin{array}{c}17,7 \\
8\end{array}$ & $\mathrm{~T}$ \\
\hline & \multicolumn{2}{|c|}{$\begin{array}{l}\text { Dana Peningkatan UKM } \\
\text { dan Naker }\end{array}$} & $\begin{array}{c}550, \\
0\end{array}$ & M \\
\hline
\end{tabular}

Sumber: http://ditpsd.kemdikbud.go.id

Peningkatan anggaran dana BOS dan pemberian kebebasan kepada sekolah untuk mengelola dana BOS menimbulkan potensi penyimpangan termasuk dalam kewajiban melakukan pemotongan dan pelaporan pajaknya. Beberapa temuan audit baik dari fungsional pemeriksa intern (Inspektorat Jenderal Kementerian Pendidikan, Kebudayaan, Riset, dan Teknologi) maupun ekstern Kementerian
Pendidikan, Kebudayaan, Riset, dan Teknologi (misalnya Badan Pemeriksa Keuangan dan Pembangunan (BPKP) dan Badan Pemeriksa Keuangan (BPK)) menunjukkan adanya penyelewengan dalam pengelolaan dana BOS. Seperti yang dilakukan oleh BPK terhadap dana BOS di Kabupaten Buleleng mengindikasikan adanya pengeluaran yang tidak sesuai termasuk adanya pemungutan pajak yang tidak sesuai ketentuan (SUYATRA, 2018). Audit juga dilakukan di berbagai daerah misalnya di Bantul (Fatim, 2021), Aceh (Jayadi, 2021), Madura (Jamal, 2021), dan Engkerang (Albar, 2021).

Untuk meningkatkan pengawasan terhadap pemotongan/pemungutan dan penyetoran pajak atas belanja yang bersumber dari Anggaran Pendapatan dan Belanja Daerah (APBD), Menteri Keuangan telah mengeluarkan regulasi Nomor 85/PMK.03/2019 (Menteri Keuangan, 2019). PMK ini mengatur tentang Mekanisme Pengawasan Terhadap Pemotongan/ Pemungutan dan Penyetoran Pajak atas Belanja yang Bersumber dari Anggaran Pendapatan dan Belanja Daerah.

Rumusan masalah yang akan dibahas dalam penelitian ini adalah mengidentifikasi faktor-faktor pemenuhan kepatuhan kewajiban perpajakan sehubungan dengan penggunaan dana bantuan operasional sekolah (BOS) oleh bendaharawan atau penanggung jawab pengelolaan penggunaan dana BOS di masing-masing unit penerima BOS yang diatur dalam SE-02/PJ./2006 (Direktorat Jenderal Pajak, 2006). Dalam aturan tersebut dijelaskan kewajiban yang harus dipenuhi oleh bendahara pemerintah maupun swasta terkait perpajakan yaitu kewajiban pendaftaran, pemotongan/pemungutan pajak, pembayaran dan pelaporan pajak.

Pemenuhan kewajiban perpajakan sehubungan dengan penggunaan dana bantuan operasional sekolah (BOS) oleh bendaharawan atau penanggung jawab pengelolaan penggunaan dana BOS di masing-masing unit penerima BOS diatur dalam SE-02/PJ./2006 (Direktorat Jenderal Pajak, 2006). Dalam aturan tersebut dijelaskan kewajiban yang harus dipenuhi oleh bendahara pemerintah maupun swasta terkait perpajakan yaitu kewajiban pendaftaran, pemotongan/pemungutan pajak, pembayaran dan pelaporan pajak.

Pada tahun 2019 diterbitkan aturan tentang NPWP Instansi Pemerintah sesuai dengan PMK Nomor 231/PMK.03/2019 tentang Tata Cara Pendaftaran dan Penghapusan Nomor Pokok Wajib Pajak, Pengukuhan dan Pencabutan Pengukuhan Pengusaha Kena Pajak, serta Pemotongan dan/atau Pemungutan, Penyetoran, dan Pelaporan Pajak bagi Instansi Pemerintah. Aturan lebih lanjut diatur 
dalam SE-12/PJ/2020 tentang Petunjuk Pelaksanaan Pembenahan Administrasi NPWP Instansi Pemerintah/Bendahara. Terkait dengan Bendahara BOS, aturan tersebut akan dilakukan penghapusan NPWP sekolah penerima dana Bantuan Operasional Sekolah (BOS) secara jabatan oleh DJP. Tanggal terdaftar Instansi Pemerintah sebagai Wajib Pajak dan tanggal Instansi Pemerintah dikukuhkan sebagai PKP yaitu tanggal 1 April 2020.

Pada praktiknya, walaupun NPWP bendahara sekolah negeri tersebut telah dihapus, namun dalam pelaksanaannya tetap memiliki kewajiban untuk memotong/memungut pajak, menyetor dan melapor atas nama Instansi Pemerintah. Oleh sebab itu penelitian ini masih relevan dan dapat digunakan oleh bendahara sekolah agar pemenuhan kepatuhan kewajiban perpajakan dapat dilaksanakan dengan benar.

Pada pasal 22 UU Nomor 28 Tahun 2007 tentang Perubahan Ketiga Atas Undang-Undang Nomor 6 Tahun 1983 tentang Ketentuan Umum dan Tata Cara Perpajakan disebutkan bahwa Menteri Keuangan dapat menetapkan "bendahara pemerintah untuk memungut pajak sehubungan dengan pembayaran atas penyerahan barang;" (Republik Indonesia, 2009). Sedangkan untuk Pajak Pertambahan Nilai (PPN) diatur dalam pasal 16A yaitu "Pajak yang terutang atas penyerahan Barang Kena Pajak dan/atau penyerahan Jasa Kena Pajak kepada Pemungut Pajak Pertambahan Nilai dipungut, disetor, dan dilaporkan oleh Pemungut Pajak Pertambahan Nilai", yang aturan turunannya diatur dalam Keputusan Menteri Keuangan Nomor 563/KMK.03/2003 tentang Penunjukan Bendaharawan Pemerintah Dan Kantor Perbendaharaan Dan Kas Negara Untuk Memungut, Menyetor, Dan Melaporkan Pajak Pertambahan Nilai Dan Pajak Penjualan Atas Barang Mewah Beserta Tata Cara Pemungutan, Penyetoran, Dan Pelaporannya. Namun khusus pembayaran untuk pembelian barang sehubungan dengan penggunaan dana Bantuan Operasional Sekolah (BOS), dikecualikan dari pemungutan Pajak Penghasilan Pasal 22. Hal ini sesuai dengan PMK No. 34/PMK.010/2017 tentang Pemungutan Pajak Penghasilan Pasal 22 Pembayaran atas Penyerahan Barang dan Kegiatan di Bidang Impor atau Kegiatan Usaha di Bidang Lain.

Terkait pengelolaan pajak, kewajiban bendahara termasuk menata usahakan Buku Pembantu Pajak. Ketentuan pajak telah diatur dalam Permendikbud No. 18 tahun 2019 yaitu di Bab V tentang Pertanggungjawaban Keuangan pada poin E, disebutkan bahwa ketentuan pajak terkait penggunaan BOS Reguler di sekolah harus mengikuti ketentuan peraturan perundangundangan mengenai pajak nasional dan pajak daerah (Peraturan Menteri Pendidikan dan Kebudayaan, 2019).

Penelitian terhadap kewajiban perpajakan dana BOS masih terbatas dilakukan sedangkan penelitian terhadap kepatuhan bendahara lainnya sudah cukup banyak dilakukan. Penelitian terkait kewajiban perpajakan bendahara dana BOS lebih bersifat kausiti seperti yang dilakukan oleh ALFAN (2017) yang dilakukan pada bendahara sekolah SDI Raudhatul Jannah dengan kesimpulan bendahara BOS belum memenuhi kewajiban perpajakannya dengan benar.

Banyak penelitian terdahulu terkait dana BOS yang pernah dilakukan adalah dilihat dari aspek pertanggungjawaban dana BOS, seperti yang dilakukan oleh Fitri (2014) yang melakukan penelitian terhadap pengelolaan dana BOS di SD di Kota Bukit Tinggi. Penelitian menggunakan metode kuantitatif dengan kuesioner kepada kepala sekolah, bendahara, dan komite sekolah dasar dengan hasil pengelolaan sudah berjalan baik diukur dengan skala Likert (Fitri, 2014). Demikian juga yang dilakukan oleh peneliti lain dengan konsep dan pendekatan yang sama yaitu pertanggungjawaban dana BOS seperti Anggraini (2001), Bhawa, Haris, and Made Artana (2014), Solikhatun (2016), Krisnayanti, Haris, and Made Artana (2015), Nugroho, Widowati, and Rihandoyo (2013), Muryati (2016), Dwiharja and Kurrohman (2013), Waldy, Fatiah, and Rizani (2020), dan Sumarni (2015).

Terdapat beberapa penelitian sebelumnya terkait dengan kepatuhan pemenuhan kewajiban perpajakan yang dilakukan oleh bendaharawan daerah atau bendahara desa. Seperti penelitian yang dilakukan oleh Subandi and Fadhil (2018) dengan melakukan analisis faktor-faktor yang mempengaruhi kepatuhan pajak bendahara desa di Kota Batu. Metode penelitian adalah kuantitatif dengan jenis penelitian adalah kuesioner dan alat analisis yang digunakan adalah analisis regresi berganda. Hasil kesimpulan dari penelitian ini adalah adanya variabel pengetahuan, pelayanan, dan sanksi memiliki hubungan signifikan baik sendiri dan bersama-sama.

Peneliti Sakina (2017) dengan judul pelaksanaan kewajiban perpajakan oleh bendahara desa dalam pengelolaan dana desa ditinjau dari asas kepatuhan di Kecamatan Berbah kota Sleman. Kesimpulan dari penelitian tersebut adalah Kewajiban bendahara desa belum optimal.

Sedangkan Ratnafuri and Herawati (2014) melakukan penelitian tentang malpraktek pemotongan dan pemungutan pajak oleh 
bendaharawan pemerintah. Penelitian dilakukan di Kota Bangkalan dengan metode kualitatif dan kesimpulan bahwa pemenuhan kewajiban perpajakan tidak benar. Penelitian sejenis juga dilakukan oleh Handayani and Zahro (2021) di SD Negeri Banyuajuh 3 Kamal Bangkalan Madura and SMK Kesehatan Yannas Husada Bangkalan.

Banyak variabel-variabel kepatuhan pajak yang telah diteliti sebelumnya dan sebagian digunakan dalam penelitian ini seperti oleh Andreoni, Erard, and Feinstein (1998) dan Allingham (1972) untuk pemeriksaan pajak dan sanksi perpajakan dengan menggunakan eksperimental study. Kirchler, Hoelzl, and Wahl (2008) mengenalkan konsep "slippery slope framework" untuk memahami kepatuhan pajak sukarela dengan berbagai variabel seperti kemungkinan diperiksa, pengetahuan perpajakan, dan denda pajak. Sedangkan WICAKSONO (2018) menggunakan variabel independen berupa tingkat pengetahuan pajak, persepsi wajib pajak dan konsultan pajak terkait tingkat kepatuhan dan persepsi keadilan sistem pajak. Sedangkan Jotopurnomo (2013) melakukan penelitian dengan variabel kesadaran Wajib Pajak, kualitas pelayanan fiskus, sanksi perpajakan dan lingkungan Wajib Pajak berada mempunyai pengaruh yang signifikan terhadap kepatuhan Wajib Pajak Orang Pribadi di Surabaya. Demikian juga yang dilakukan Susmita (2016) melakukan penelitian terhadap kepatuhan Wajib Pajak di KPP Pratama Denpasar Timur dengan variabel pengaruh kualitas pelayanan, sanksi perpajakan, biaya kepatuhan pajak, dan penerapan e-filing.

Kerangka teoritis dari penelitian ini menggunakan tiga variabel independen seperti penelitian terdahulu yaitu tingkat pelayanan pajak berpengaruh terhadap kepatuhan pajak Bendahara BOS, tingkat sanksi pajak berpengaruh terhadap kepatuhan pajak Bendahara BOS, dan pemeriksaan pajak berpengaruh terhadap kepatuhan pajak Bendahara BOS (Alm, 2019; Andreoni et al., 1998; Jotopurnomo, 2013; Sakina, 2017; Susmita, 2016).

Untuk variabel dependen dipilih tingkat kepatuhan Bendahara BOS sebagai variabel Y. Berbeda dengan penelitian Andreoni et al. (1998) yang menggunakan eksperimental study, penelitian ini menggunakan instrumen untuk mengukur kepatuhan pajak merujuk pada hasil kuesioner.

Arah hubungan antara satu variabel dengan variabel lain adalah positif. Hal ini dapat dilihat dari penelitian sebelumnya (Andreoni et al., 1998; Subandi \& Fadhil, 2018).

Tujuan dari penelitian ini adalah untuk menguji apakah pelayanan perpajakan, pemberian sanksi perpajakan, dan pemeriksaan pajak tersebut mempengaruhi kepatuhan perpajakan Bendahara BOS.

Menurut data dari portal Mendikbuddikti, jumlah Bantuan Operasional Sekolah (BOS) di 157 sekolah SD negeri dan 22 SMP negeri di kota Tangerang Selatan sebesar Rp 16,982,840,000; dengan jumlah 100.546 siswa (Kementerian Pendidikan dan Kebudayaan, 2019). Jumlah ini cukup signifikan serta memiliki potensi yang cukup besar dalam hal pemungutan dan pemotongan pajak oleh bendahara sekolahnya. Ketidakpatuhan dalam melakukan pemotongan dan pemungutan serta pelaporan pajak dapat menurunkan potensi penerimaan pajaknya. Oleh sebab itu sekolah tersebut dipilih sebagai sampel dalam penelitian ini.

Mengingat jumlah dana BOS yang telah didistribusikan ke tiap-tiap sekolah cukup signifikan namun tidak diimbangi dengan jumlah pembayaran pajak dan kepatuhan dalam pelaporannya, perlu dilakukan penelitian lebih dalam mengenai penyebab dan bagaimana solusinya. Hasil temuan dalam penelitian ini akan sangat bermanfaat bagi Direktorat Jenderal Pajak dalam menyelesaikan permasalahan bendahara secara umum. Selain itu rekomendasi dari penelitian ini dapat digunakan untuk mengurangi potensi temuan Badan Pemeriksa Keuangan terhadap sanksi yang harus dikenakan pada bendahara akibat ketidakpatuhan dalam pembayaran dan pelaporan pajaknya.

\section{KERANGKA TEORI DAN PENGEMBANGAN HIPOTESIS}

Pengembangan teori kepatuhan yang digunakan adalah the principal-agent framework dan game theory sebagaimana dikembangkan oleh Graetz, Reinganum, and Wilde (1984) serta economics-of-crime approach oleh Alm (2019).

Prinsip the principal-agent framework ini memandang kantor pajak sebagai principal dan bendahara sebagai agent. Jika antara principal dan agent ini tidak sejalan maka akan menimbulkan principal-agent problem atau agency problem (Titman \& Keown, 2018). Hubungan antara perilaku tax payer dan tax authority juga menjadi tantangan di masa depan dalam peningkatan kepatuhan (Slemrod \& Yitzhaki, 2002). Salah satu upaya mengurangi konflik tersebut adalah dengan monitoring dan pemberian kompensasi atau pelayanan dari prinsipal.

Game theory ini menurut Graetz et al. (1984) menekankan bahwa pemeriksaan pajak dan sanksi pajak memegang peran penting dalam kepatuhan pajak karena adanya faktor kemungkinan diperiksa oleh otoritas perpajakan. Semakin tinggi sanksi dan 
semakin besar peluang diperiksa akan menyebabkan tingkat kepatuhan juga akan meningkat. Ini juga konsisten dengan penelitian oleh Kirchler et al. (2008).

Pendekatan economics-of-crime approach juga menunjukkan bahwa tingkat kepatuhan tergantung pada penegakan hukum (Alm, 2019). Kekhawatiran terhadap diperiksa dan dikenakan sanksi menjadi salah satu faktor pendorong kepatuhan.

Jika dikaitkan dengan penelitian ini maka semakin tinggi tingkat pelayanan, sanksi perpajakan, dan pemeriksaan pajak akan mendorong tingkat kepatuhan bendahara yang semakin tinggi juga. Demikian pula antar variabel independen, dapat secara bersama-sama mempengaruhi tingkat kepatuhan bendahara BOS dalam memenuhi kewajiban perpajakannya.

Berdasarkan teori diatas disusunlah hipotesis pada penelitian ini yaitu:

H1. Tingkat sosialisasi pajak berpengaruh terhadap kepatuhan pajak Bendahara BOS

Semakin baik pengetahuan pajak dari sosialisasi, semakin tinggi tingkat kepatuhan pajak Bendahara BOS.

H2. Tingkat sanksi pajak berpengaruh terhadap kepatuhan pajak Bendahara BOS

Semakin baik pemahaman adanya sanksi pajak, semakin tinggi tingkat kepatuhan pajak Bendahara BOS.

H3. Pemeriksaan pajak mempengaruhi kepatuhan pajak Bendahara BOS

Semakin baik pemahaman adanya sanksi pajak, semakin tinggi tingkat kepatuhan pajak Bendahara BOS.

\section{METODE PENELITIAN}

Penelitian ini dilakukan dengan menggunakan data primer berupa hasil kuesioner kepada pengelola dana BOS di sekolah negeri yang ada di Tangerang Selatan. Pemilihan wilayah di kota Tangerang Selatan ini karena alokasi dana BOS cukup besar serta jumlah sekolah yang cukup banyak untuk Provinsi Banten.

Untuk literatur, peneliti memperoleh data dari laman Dinas Pendidikan dan Kebudayaan Kota Tangerang Selatan, buku-buku, jurnal, dan media lainnya.

Untuk variabel kepatuhan pajak digunakan kriteria sesuai SE-02/PJ./2006 dengan penyesuaian sesuai PMK Nomor 231/PMK.03/2019 dan SE12/PJ/2020, yaitu kepatuhan pajak, pelayanan pajak, sanksi pajak, dan pemeriksaan pajak.

Berbeda dengan penelitian yang dilakukan oleh oleh Andreoni et al. (1998) dan Allingham (1972) yang menggunakan eksperimental study untuk menguji kepatuhan pajak, pada penelitian ini, digunakan pemodelan SEM dengan dua jenis variabel, yakni variabel independen (exogent variable) dan variabel dependen (endogent variable). Pada pemodelan SEM, variabel independen dikenal juga sebagai variabel eksogen sedangkan variabel dependen dikenal juga sebagai variabel endogen. Pada penelitian ini kepatuhan pajak menjadi variabel eksogen. Sugiyono (2015) menjelaskan bahwa variabel independen adalah variabel yang menjadi penyebab terpengaruhnya variabel dependen menjadi variabel endogen. Kemudian Sugiyono (2015) juga menjelaskan terkait dengan variabel dependen, yakni variabel yang dipengaruhi atau terikat dan mendapatkan pengaruh dari variabel independen. Pada penelitian ini pelayanan pajak, sanksi pajak, dan pemeriksaan pajak menjadi variabel endogen.

Berdasarkan kajian-kajian teori kepatuhan, selanjutnya model tersebut dianalisis keakuratannya melalui Metode Structural Equation Modeling (SEM) dan diuji dengan menggunakan Smart PLS. Kajian kepatuhan pajak dengan menggunakan PLS-SEM ini masih sangat terbatas. Studi literatur sebelumnya menghasilkan penggunaan metode tersebut untuk melihat efektivitas pemanfaatan dana BOS (Danilwan, 2010) dan ethical behavior dan ethical climate (Fauzan, Sulistyo, \& Rita Indah Mustikowati, 2016) serta transparansi penggunaan dana BOS (Hidayah \& Badawi, 2018). Hair Jr et al. (2017) menjelaskan bahwa PLS merupakan salah satu metode dari SEM yang berbasis varian dan didesain untuk menyelesaikan regresi berganda ketika terjadi permasalahan spesifik pada data, sebagai contoh adalah multikolinearitas, adanya missing values, serta ukuran sampel penelitian yang tidak besar. Wong (2019) menjelaskan beberapa keunggulan dari PLS-SEM ini antara lain adalah mudah diinterpretasikan pada model yang kompleks, dapat dijalankan dengan sampel yang tidak banyak, informasi yang dihasilkan efisien, dapat menguji model penelitian dengan dasar teori yang lemah, hasil tetap kokoh walaupun terdapat missing value, mampu mengelola masalah multikolinearitas, atau data tidak normal, serta dapat digunakan pada tipe data nominal, ordinal, kontinu, dll.

\section{HASIL PENELITIAN}

Untuk melakukan uji hipotesis, pada tahap awal, penulis akan melakukan prosedur statistik deskriptif pada data yang telah dikumpulkan. Sugiyono (2015) menjelaskan bahwa analisis statistik deskriptif merupakan prosedur yang digunakan untuk melakukan uji hipotesis, pada tahap awal, penulis akan melakukan prosedur 
statistik deskriptif pada data yang telah dikumpulkan.

\subsection{Evaluasi Model Pengukuran (Outer Model)}

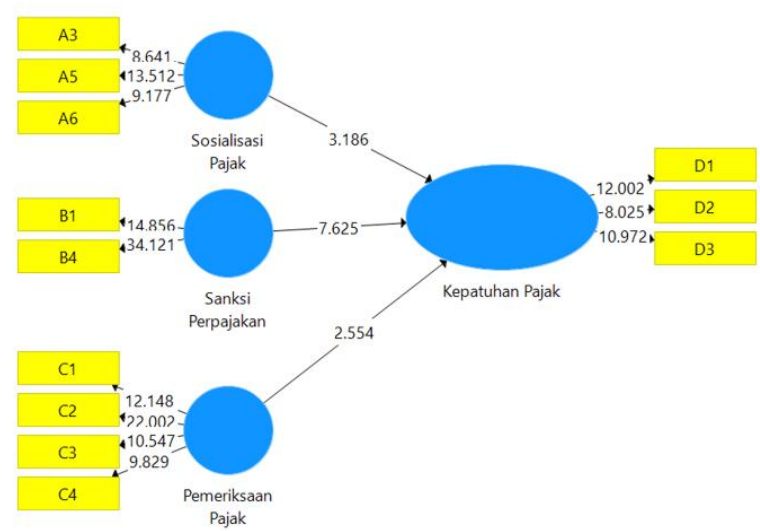

Evaluasi model dilakukan sebelum melakukan uji hipotesis. Ghozali and Ratmono (2013) dalam penelitiannya menyebutkan bahwa evaluasi model dilakukan dengan menilai model pengukuran (outer model) serta model struktural (inner model). Menurut Hair Jr et al. (2017) dan Sarstedt, Ringle, and Hair (2020) dalam penelitiannya menyatakan bahwa terdapat tiga teknik analisis data untuk melakukan penilaian model pengukuran (outer model), yaitu uji validitas yang terdiri dari uji validitas konvergen (convergent validity), dan uji validitas diskriminant (discriminant validity), serta uji reliabilitas (reliability test).

Wong (2019) menyatakan bahwa dalam melakukan uji convergent validity, diperlukan penilaian pada outer loadings dan average variance extracted (AVE).

Tabel 1 Hasil Uji Outer Loadings

\begin{tabular}{|c|r|r|r|r|}
\hline & $\begin{array}{c}\text { Kepatuhan } \\
\text { Pajak }\end{array}$ & $\begin{array}{c}\text { Pemeriksaan } \\
\text { Pajak }\end{array}$ & $\begin{array}{c}\text { Sanksi } \\
\text { Perpajakan }\end{array}$ & $\begin{array}{c}\text { Sosialisasi } \\
\text { Pajak }\end{array}$ \\
\hline A3 & & & & 0,752 \\
\hline A5 & & & & 0,801 \\
\hline A6 & & & & 0,761 \\
\hline B1 & & & 0,851 & \\
\hline B4 & & & 0,885 & \\
\hline C1 & & 0,780 & & \\
\hline C2 & & 0,821 & & \\
\hline C3 & & 0,707 & & \\
\hline C4 & & 0,773 & & \\
\hline D1 & 0,775 & & & \\
\hline D2 & 0,726 & & & \\
\hline D3 & 0,823 & & & \\
\hline
\end{tabular}

Nilai outer loadings menurut Hulland (1999) yang disarankan adalah di atas 0,700. Pada Tabel diatas dapat dilihat bahwa seluruh nilai outer loadings bernilai di atas 0,700. Hasil tersebut menunjukkan bahwa penelitian ini telah memenuhi uji outer loadings sebagai salah satu komponen convergent validity.

Pengujian selanjutnya terkait dengan convergent validity adalah average variance extracted (AVE). Berikut merupakan hasil uji average variance extracted (AVE) yang dijelaskan pada tabel berikut.

Tabel 2 Hasil Uji Average Variance Extracted (AVE)

\begin{tabular}{|l|r|r|r|r|}
\hline $\begin{array}{c}\text { Construct Reliability } \\
\text { and Validity }\end{array}$ & $\begin{array}{c}\text { Cronbach's } \\
\text { Alpha }\end{array}$ & rho_A & $\begin{array}{c}\text { Composite } \\
\text { Reliability }\end{array}$ & $\begin{array}{c}\text { Average Variance } \\
\text { Extracted (AVE) }\end{array}$ \\
\hline Kepatuhan Pajak & 0,669 & 0,670 & 0,819 & 0,602 \\
\hline Pemeriksaan Pajak & 0,774 & 0,792 & 0,854 & 0,595 \\
\hline Sanksi Perpajakan & 0,674 & 0,681 & 0,859 & 0,754 \\
\hline Sosialisasi Pajak & 0,661 & 0,660 & 0,815 & 0,595 \\
\hline
\end{tabular}

Bagozzi and Yi (1988) dan Hair, Ringle, and Sarstedt (2011) menyatakan bahwa nilai average variance extracted (AVE) yang disarankan adalah di atas 0,500. Pada tabel tersebut dapat dilihat bahwa seluruh nilai average variance extracted (AVE) bernilai di atas 0,500. Hasil tersebut menunjukkan bahwa penelitian ini telah memenuhi uji average variance extracted (AVE) dan outer loadings sebagai komponen convergent validity.

Setelah melakukan uji convergent validity, maka pengujian selanjutnya adalah terkait dengan discriminant validity. Uji convergent validity dilakukan dengan penilaian pada Fornell Lacker Criterion dan cross loadings factor. Berikut merupakan hasil uji Fornell Lacker Criterion yang dijelaskan pada tabel berikut.

Tabel 3 Hasil Uji Fornell Locker Criteriation

\begin{tabular}{|l|r|r|r|r|}
\hline $\begin{array}{c}\text { Fornell-Larcker } \\
\text { Criterion }\end{array}$ & $\begin{array}{c}\text { Kepatuhan } \\
\text { Pajak }\end{array}$ & $\begin{array}{c}\text { Pemeriksaan } \\
\text { Pajak }\end{array}$ & $\begin{array}{c}\text { Sanksi } \\
\text { Perpajakan }\end{array}$ & $\begin{array}{c}\text { Sosialisasi } \\
\text { Pajak }\end{array}$ \\
\hline Kepatuhan Pajak & 0,776 & & & \\
\hline Pemeriksaan Pajak & 0,611 & 0,771 & & \\
\hline Sanksi Perpajakan & 0,781 & 0,430 & 0,868 & \\
\hline Sosialisasi Pajak & 0,635 & 0,622 & 0,424 & 0,772 \\
\hline
\end{tabular}

Fornell and Larcker (1981) menyatakan bahwa nilai AVE antara suatu variabel dengan variabel itu sendiri harus lebih besar daripada suatu variabel dengan variabel lainnya. Pada tabel tersebut dapat dilihat bahwa sebagian besar nilainya lebih besar dibandingkan dengan variabel lainnya kecuali untuk sanksi perpajakan terhadap kepatuhan pajak.

Pengujian selanjutnya terkait dengan discriminant validity adalah cross loadings factor. Berikut merupakan hasil cross loadings factor yang dijelaskan pada tabel berikut.

Tabel 4 Hasil Uji Cross Loadings

\begin{tabular}{|r|r|r|r|r|}
\hline & $\begin{array}{c}\text { Kepatuhan } \\
\text { Pajak }\end{array}$ & $\begin{array}{r}\text { Pemeriksaan } \\
\text { Pajak }\end{array}$ & $\begin{array}{c}\text { Sanksi } \\
\text { Perpajakan }\end{array}$ & $\begin{array}{c}\text { Sosialisasi } \\
\text { Pajak }\end{array}$ \\
\hline A3 & 0,532 & 0,364 & 0,379 & $\mathbf{0 , 7 5 2}$ \\
\hline A5 & 0,465 & 0,579 & 0,321 & $\mathbf{0 , 8 0 1}$ \\
\hline A6 & 0,465 & 0,510 & 0,271 & $\mathbf{0 , 7 6 1}$ \\
\hline B1 & 0,635 & 0,287 & $\mathbf{0 , 8 5 1}$ & 0,255 \\
\hline B4 & 0,717 & 0,450 & $\mathbf{0 , 8 8 5}$ & 0,468 \\
\hline C1 & 0,455 & $\mathbf{0 , 7 8 0}$ & 0,350 & 0,466 \\
\hline C2 & 0,577 & $\mathbf{0 , 8 2 1}$ & 0,461 & 0,590 \\
\hline C3 & 0,399 & $\mathbf{0 , 7 0 7}$ & 0,230 & 0,449 \\
\hline C4 & 0,424 & $\mathbf{0 , 7 7 3}$ & 0,239 & 0,383 \\
\hline D1 & $\mathbf{0 , 7 7 5}$ & 0,656 & 0,582 & 0,646 \\
\hline D2 & $\mathbf{0 , 7 2 6}$ & 0,325 & 0,617 & 0,449 \\
\hline D3 & $\mathbf{0 , 8 2 3}$ & $\mathbf{0 , 4 0 4}$ & 0,619 & 0,350 \\
\hline
\end{tabular}


Kresnandra (2016) menyatakan bahwa dalam melakukan penilaian pada uji cross loadings factor, hubungan construct dengan variabel pengukuran harus lebih besar daripada ukuran construct lainya dan nilai cross loadings yang disarankan harus diatas 0,700. Pada tabel tersebut dapat dilihat bahwa seluruh nilai cross loadings bernilai di atas 0,700 , serta hubungan construct dengan variabel pengukuran lebih besar dari ukuran construct lainnya. Hasil tersebut menunjukkan bahwa penelitian ini telah memenuhi uji Fornell Lacker Criterion dan outer loadings sebagai komponen discriminant validity.

Setelah penelitian telah memenuhi kriteria uji convergent validity dan discriminant validity, maka pengujian selanjutnya adalah terkait dengan reliability. Uji reliability dilakukan dengan penilaian pada composite reliability. Berikut merupakan hasil uji composite reliability yang dijelaskan pada tabel berikut.

Tabel 5 Hasil Uji Composite Reliability

\begin{tabular}{|l|r|}
\hline Construct Reliability and Validity & Composite Reliability \\
\hline Kepatuhan Pajak & 0,819 \\
\hline Pemeriksaan Pajak & 0,854 \\
\hline Sanksi Perpajakan & 0,859 \\
\hline Sosialisasi Pajak & 0,815 \\
\hline
\end{tabular}

Bagozzi and Yi (1988) menyatakan bahwa nilai composite reliability yang disarankan adalah di atas 0,700 . Pada tabel diatas dapat dilihat bahwa seluruh nilai composite reliability bernilai di atas 0,700 . Hasil tersebut menunjukkan bahwa penelitian ini telah memenuhi uji reliability.

\subsection{Evaluasi Uji Multikolinieritas}

Pengujian model untuk multikolinieritas adalah untuk melihat ada atau tidak hubungan antar variable independent untuk model formatif dengan melihat variance inflation factor (VIF). Jika nilai VIP 5 atau lebih menunjukkan terdapat masalah dalam multikolinieritas (Hair et al., 2011). Pada tabel berikut menunjukkan nilai VIF dibawah 5 yang berarti tidak ada isu terkait multikolinieritas.

Tabel 6 Uji Multikolinieritas

\begin{tabular}{|l|r|l|l|l|}
\hline \multicolumn{1}{|c|}{ Inner VIF Values } & $\begin{array}{c}\text { Kepatuhan } \\
\text { Pajak }\end{array}$ & $\begin{array}{c}\text { Pemeriksaan } \\
\text { Pajak }\end{array}$ & $\begin{array}{c}\text { Sanksi } \\
\text { Perpajakan }\end{array}$ & $\begin{array}{c}\text { Sosialisasi } \\
\text { Pajak }\end{array}$ \\
\hline Kepatuhan Pajak & & & & \\
\hline Pemeriksaan Pajak & 1,725 & & & \\
\hline Sanksi Perpajakan & 1,290 & & & \\
\hline Sosialisasi Pajak & 1,713 & & & \\
\hline
\end{tabular}

\subsection{Evaluasi Model Struktural (Inner Model)}

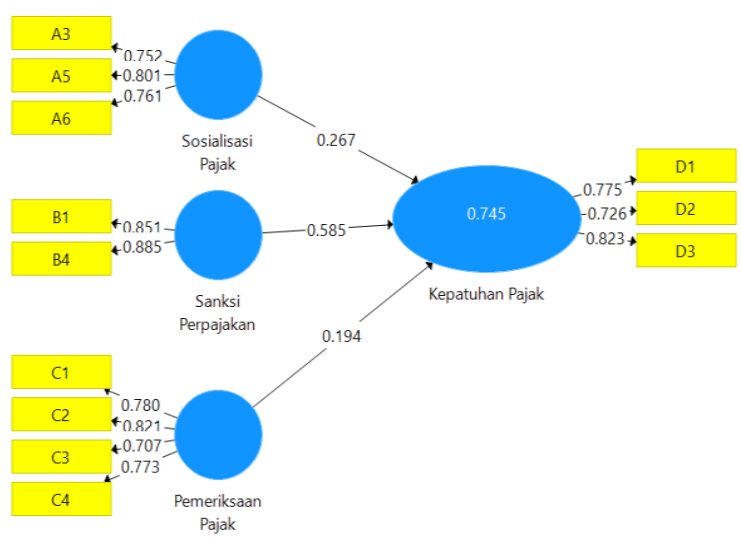

Penelitian ini telah memenuhi kriteria penilaian pada evaluasi model pengukuran (outer model), maka evaluasi yang selanjutnya dilakukan adalah evaluasi model struktural (inner model). Ghozali and Ratmono (2013) menyampaikan bahwa evaluasi inner model dimulai dengan menilai RSquare untuk setiap variabel laten endogen untuk mengukur kekuatan prediksi dari inner model. Berikut merupakan hasil uji composite reliability yang dijelaskan pada tabel berikut.

Tabel 7 Hasil Uji R-Square, Hasil Uji Normed Fit Index, dan Hasil Uji Path Coefficient

\begin{tabular}{|c|c|c|}
\hline & R Square $\mathbf{F}$ & R Square Adjus \\
\hline Kepatuhan Paja & 0,745 & 0 \\
\hline Fit Summary & Saturated Model & I Estimated Model \\
\hline \begin{tabular}{|l|} 
SRMR \\
\end{tabular} & $\begin{array}{r}0,119 \\
\end{array}$ & 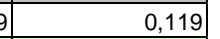 \\
\hline d_ULS & 1,109 & 1,109 \\
\hline d_G & 0,436 & 0,436 \\
\hline Chi-Square & 210,418 & 210,418 \\
\hline NFI & 0,561 & 0,561 \\
\hline
\end{tabular}

\begin{tabular}{|l|r|r|r|r|r|}
\hline & $\begin{array}{c}\text { Original } \\
\text { Sample (0) }\end{array}$ & $\begin{array}{c}\text { Sample } \\
\text { Mean (M) }\end{array}$ & $\begin{array}{c}\text { Standard } \\
\text { Deviation (STDEV) }\end{array}$ & $\begin{array}{c}\text { T Statistics } \\
(\mid \mathbf{O} / \text { STDEV|) }\end{array}$ & P Values \\
\hline H1 & 0,267 & 0,260 & 0,078 & 3,434 & 0,001 \\
\hline H2 & 0,585 & 0,587 & 0,076 & 7,740 & 0,000 \\
\hline H3 & 0,194 & 0,197 & 0,075 & 2,565 & 0,011 \\
\hline
\end{tabular}

Hasil pengujian inner modal yang disajikan pada tabel diatas menunjukkan besarnya R-Square untuk variabel endogen kepatuhan adalah 0,745 dan hampir mendekati kuat (Hair et al., 2011). Nilai RSquare pada variabel kepatuhan pajak sebesar 0,745 dapat diartikan bahwa sebesar 74,5\% variabel kepatuhan pajak dapat dijelaskan oleh variabel sosialisasi, sanksi, dan pemeriksaan pajak, sedangkan sekitar $25,5 \%$ sisanya dijelaskan oleh variabel lain yang berada di luar model.

Model struktural pada penelitian ini telah memiliki goodness of fit yang baik yang terlihat dari nilai $Q^{2}$ sebesar 0,745 yang artinya besarnya data penelitian yang dapat dijelaskan oleh model struktural dalam penelitian ini adalah sebesar $74,5 \%$. Selain itu pada pengujian indicator model fit dengan melihat nilai pada Normed Fit Index (NFI) atau Bentler and Bonett Index yang dikenalkan oleh 
Bentler and Bonett (1980) menunjukkan angka 0,561 sehingga dapat dikatakan sebagai model fit.

\subsection{Hasil Uji Hipotesis}

Untuk menguji signifikansi dari hipotesis, maka dilakukan penilaian $t$-statistics. Hipotesis dalam penelitian ini menggunakan penilaian uji hipotesis satu arah (one tailed). Wong (2019) menyatakan bahwa hipotesis diterima jika nilai t-statistics lebih besar dari 1,64. Dari tersebut terlihat bahwa $\mathrm{H} 1$, $\mathrm{H} 2$, dan $\mathrm{H} 3$ nilainya melebihi 1,64 sehingga dinilai signifikan dan diterima.

Untuk nilai Signifikansi (Sig) variabel pelayanan adalah sebesar 0,001. Karena nilai Sig. 0,001 < probabilitas 0,05, maka dapat disimpulkan bahwa tingkat kualitas pelayanan yang mempengaruhi kepatuhan secara signifikan. Bendahara merasa terbantu dengan adanya pelayanan yang baik misalnya dalam bentuk sosialisasi. Hal ini sudah menjadi perhatian bagi Direktorat Jenderal Pajak untuk lebih memberikan pelayanan dan sosialisasi sehingga memudahkan bendahara dalam menghitung pajak. Berbeda dengan tingkat kepatuhan pembayaran pajak yang telah dilakukan oleh bendahara yang cukup tinggi karena adanya fungsi pengawas dari dinas pendidikan maupun inspektorat jenderal pendidikan.

Untuk nilai Signifikansi (Sig) variabel sanksi pajak adalah sebesar 0,000. Karena nilai Sig. 0,000 < probabilitas 0,05, maka dapat disimpulkan bahwa $\mathrm{H} 2$ atau hipotesis kedua diterima. Artinya ada pengaruh signifikan atas sanksi pajak terhadap kepatuhan pajaknya. Pemberian sanksi tersebut diharapkan dapat meningkatkan kepatuhan terutama karena harus membayar sanksi yang tidak ada mata anggarannya sehingga merugikan bagi bendahara itu sendiri.

Dari tabel diatas diketahui nilai Signifikansi (Sig) variabel pemeriksaan pajak adalah sebesar 0,011 < probabilitas 0,05, maka dapat disimpulkan bahwa H3 atau hipotesis ketiga diterima. Artinya bahwa pemeriksaan pajak berpengaruh signifikan dan positif terhadap kepatuhan. Pemeriksaan pajak baik yang dilakukan oleh Direktorat Jenderal Pajak, Inspektorat Jenderal Kementerian Pendidikan, atau Badan Pemeriksa Keuangan (BPK) dapat menjadi pembenaran bahwa risiko untuk diperiksa terhadap para bendahara tersebut dapat terjadi.

Hasil dari penelitian ini sejalan dengan teori dan penelitian terdahulu yang melihat kualitas pelayanan, sanksi pajak dan pemeriksaan pajak berpengaruh pada terciptanya kepatuhan pajak (Alm, 2019; Andreoni et al., 1998; Graetz et al., 1984; Hanlon, Mills, \& Slemrod, 2005; Kirchler et al., 2008).

\section{KESIMPULAN DAN SARAN}

Berdasarkan hasil penelitian ini dapat disimpulkan bahwa ada ketiga faktor yaitu kualitas pelayanan, sanksi pajak, dan pemeriksaan pajak berpengaruh pada terciptanya kepatuhan pajak bendahara khususnya bendahara BOS. Pelayanan yang diberikan oleh Direktorat Jenderal Pajak kepada Wajib Pajak, terutama bendahara sekolah mampu meningkatkan kepatuhan perpajakannya. Pelaporan melalui e-filing di beberapa literatur mampu memberikan efek yang signifikan dalam memudahkan pelaporan wajib pajak. Pemberian sanksi terhadap ketidakpatuhan dalam pelaporan dan pembayaran pajak juga mampu mendorong timbulnya efek jera bagi wajib pajak dalam hal ini bendahara BOS. Otoritas perpajakan diharapkan dapat memberikan pengawasan yang lebih efektif lagi sehingga proses pemberian sanksi tersebut dapat dilakukan sesuai dengan ketentuan yang berlaku. Pemeriksaan pajak juga menjadi perhatian baik bagi bendahara maupun DJP. Efek dari pelaporan yang tidak benar dapat berakibat pada dilakukannya pemeriksaan oleh DJP. Selain itu banyak pihak yang juga melakukan pengawasan dan pemeriksaan terhadap pengelolaan dana BOS. Oleh sebab itu perlu kesadaran dari bendahara untuk menghitung dan melaporkan perpajakan instansi pemerintahnya dengan benar.

\section{IMPLIKASI DAN KETERBATASAN}

Implikasi yang diperoleh dari penelitian ini adalah perlunya bagi otoritas perpajakan dalam memprioritaskan hal-hal yang dapat meningkatkan kepatuhan perpajakan yaitu kualitas pelayanan, sanksi pajak, dan pemeriksaan pajak.

Penelitian ini memiliki keterbatasan yaitu tidak dapat dipublikasikan secara detail pelaporan SPT dan pembayaran pajaknya mengingat adanya kerahasiaan sebagaimana diatur dalam ketentuan perpajakan. Penelitian selanjutnya dapat memperluas cakupan sampel yang digunakan serta mempertimbangkan faktor-faktor lainnya yang mempengaruhi kepatuhan pajak.

\section{DAFTAR PUSTAKA (REFERENCES)}

Albar, M. A. (2021). Inspektorat Enrekang Audit SPJ Penggunaan Dana BOS Anggaran 2020.

ALFAN, M. (2017). ANALISIS ASPEK PERPAJAKAN ATAS BANTUAN OPERASIONAL SEKOLAH (BOS) DI SDI RAUDLATUL JANNAH. Universitas Airlangga,

Allingham, M. G., \& Sandmo, A. (1972). Income tax evasion: A theoretical analysis. Taxation: critical perspectives on the world economy, . 3, 323-338. 
Alm, J. (2019). Tax compliance and administration. In Handbook on taxation (pp. 741-768): Routledge.

Andreoni, J., Erard, B., \& Feinstein, J. (1998). Tax compliance. Journal of economic literature, 36(2), 818-860.

Anggraini, R. D. (2001). Transparansi, partisipasi, dan akuntabilitas pengelolaan anggaran dana BOS dalam program RKAS di SDN Pacarkeling VIII Surabaya. Sumber, 21(23), 21-77.

Bagozzi, R. P., \& Yi, Y. (1988). On the Evaluation of Structural Equation Models. Journal of the Academy of Marketing Science, 16(1), 7494. doi:10.1007/BF02723327

Bentler, P. M., \& Bonett, D. G. (1980). Significance tests and goodness of fit in the analysis of covariance structures. Psychological bulletin, 88(3), 588.

Bhawa, G. A. S., Haris, I. A., \& Made Artana, M. P. (2014). Efektivitas Pengelolaan Dana Bantuan Operasional Sekolah (BOS) Pada Sekolah Dasar di Kecamatan Sukasada. Jurnal Pendidikan Ekonomi Undiksha, 4(1).

Danilwan, Y. (2010). HAMBATAN PENYALURAN DANA BANTUAN OPERASIONAL SEKOLAH (STUDI KASUS DI PROPINSI SUMATERA UTARA). EKUITAS (Jurnal Ekonomi dan Keuangan), 14(4), 539-554.

PEDOMAN PELAKSANAAN PEMENUHAN KEWAJIBAN PERPAJAKAN SEHUBUNGAN DENGAN PENGGUNAAN DANA BANTUAN OPERASIONAL SEKOLAH (BOS) OLEH BENDAHARAWAN ATAU PENANGGUNG JAWAB PENGELOLAAN PENGGUNAAN DANA BOS DI MASING-MASING UNIT PENERIMA BOS, (2006).

Dwiharja, L. M., \& Kurrohman, T. (2013). Pengaruh Akuntabilitas Dan Transparansi Pengelolaan Anggaran Pendapatan Dan Belanja Sekolah (APBS) Terhadap Partisipasi Komite Sekolah (Studi Empiris Pada Sekolah Dasar Negeri Se Kecamatan Patrang Kabupaten Jember). jrak, 373.

Fatim. (2021). Irjen Kemenag RI Audit Dana BOS MIN 2 Bantul. Retrieved from https://kemenagbantul.org/irjenkemenag-ri-audit-dana-bos-min-2-bantul

Fauzan, F., Sulistyo, S., \& Rita Indah Mustikowati, R. (2016). Pengaruh Religiusitas Dan Good Governance Terhadap Ethical Behavior Dengan Ethical Climate Sebagai Variabel Mediating Dalam Pengelolaan Dana Bantuan Operasional Sekolah.

Fitri, A. (2014). Pengelolaan Dana Bantuan Operasional Sekolah (BOS) Sekolah Dasar
Negeri Kecamatan Mandiangin Koto Selayan Kota Bukittinggi. Jurnal Bahana Manajemen Pendidikan, 2(1), 33-39.

Fornell, C., \& Larcker, D. F. (1981). Evaluating Structural Equation Models with Unobservable Variables and Measurement Error. Journal of Marketing Research, 18(1), 39-50.

Ghozali, I., \& Ratmono, D. (2013). Analisis multivariat dan ekonometrika: Teori, konsep, dan aplikasi dengan EVIEWS 8. Semarang: Badan Penerbit Universitas Diponegoro.

Graetz, M. J., Reinganum, J. F., \& Wilde, L. L. (1984). A Model of Tax Compliance Under BudgetConstrained Auditors.

Hair, J. F., Ringle, C. M., \& Sarstedt, M. (2011). PLSSEM: Indeed a silver bullet. Journal of Marketing theory and Practice, 19(2), 139152.

Hair Jr, J. F., M.Hult, G. T., M.Ringle, C., \& Sarstedt, M. (2017). A Primer on Partial Least Squares Structural Equation Modeling (PLS-SEM).

Handayani, N., \& Zahro, M. (2021). Potret Pemotongan dan Pemungutan Pajak oleh Bendahara Dana Bantuan Operasional Sekolah (BOS). Wahana Riset Akuntansi, 9(1), 62-79.

Hanlon, M., Mills, L. F., \& Slemrod, J. B. (2005). An empirical examination of corporate tax noncompliance. Ross School of Business Paper(1025).

Hidayah, N., \& Badawi, A. (2018). Factors Affecting The Accountability of The Use of School Operational Assistance Fund at State Elementary School In West Jakarta Indonesia.

Hulland, J. (1999). Use of Partial Least Squares (PLS) in Strategic Management Research: A Review of Four Recent. Strategic Management Journal, 20(2), 195-204.

Jamal. (2021). BPK Audit Pengunaan Dana BOS SMPN di Bangkalan.

Jayadi, F. (2021). Kepala Sekolah Satu Kabupaten Kebingungan, BPK Mau Audit Dana BOS. Retrieved from https://rri.co.id/daerah/772327/kepalasekolah-satu-kabupaten-kebingunganbpk-mau-audit-dana-bos

Jotopurnomo, C., and Yenni Mangoting. (2013). Pengaruh kesadaran wajib pajak, kualitas pelayanan fiskus, sanksi perpajakan, lingkungan wajib pajak berada terhadap kepatuhan wajib pajak orang pribadi di 
Surabaya. Tax \& Accounting Review 1, no. $1,1,49$.

Kirchler, E., Hoelzl, E., \& Wahl, I. (2008). Enforced versus voluntary tax compliance: The "slippery slope" framework. Journal of Economic psychology, 29(2), 210-225.

Kresnandra, A. A. N. A. (2016). Pengaruh Desentralisasi Fiskal Terhadap Pertumbuhan Ekonomi Daerah Dengan Dana Perimbangan Dan Investasi Swasta Sebagai Variabel Pemoderasi. Jurnal Bisnis dan Manajemen, 3(2).

Krisnayanti, I. A. P. A., Haris, I. A., \& Made Artana, M. P. (2015). Analisis Persepsi Stakeholder Internal dan Eksternal terhadap Transparansi dan Akuntabilitas Laporan Keuangan Pengelolaan Dana BOS di SMP Negeri 1 Banjar Tahun 2013. Jurnal Pendidikan Ekonomi Undiksha, 4(1).

Mekanisme Pengawasan terhadap Pemotongan/Pemungutan dan Penyetoran Pajak atas Belanja yang Bersumber dari Anggaran Pendapatan dan Belanja Daerah, (2019).

Muryati, I. (2016). Pengelolaan Dana Bos pada SD Negeri Di UPT Pelayanan Pendidikan Kecamatan Moyudan Kabupaten Sleman. Jurnal Akuntabilitas Manajemen Pendidikan, 4(2), 237-246.

Nugroho, R. W., Widowati, N., \& Rihandoyo, R. (2013). Implementasi Kebijakan Penggunaan Dana Bantuan Operasional Sekolah di Kota Semarang (Studi Kasus di Sekolah Menengah Pertama Negeri Semarang Selatan Tahun 2011). Journal of Public Policy and Management Review, 2(1), 171-178.

Peraturan Menteri Pendidikan dan Kebudayaan. (2019). Peraturan Menteri Pendidikan dan Kebudayaan Nomor 18 Tahun 2019 tentang Petunjuk Teknis Bantuan Operasional Sekolah Reguler.

Permendikbud, M. P. d. K. (2019). Komponen Biaya BOS. Retrieved from https://bos.kemdikbud.go.id/index.php

Ratnafuri, K., \& Herawati, N. (2014). Malpraktek Pemotongan Dan Pemungutan Pajak Oleh Bendaharawan Pemerintah. Jurnal Akuntansi Multiparadigma, 3(3), 471-492.

Undang-Undang Nomor 36 Tahun 2008 tentang Perubahan Keempat atas Undang-Undang Nomor 7 Tahun 1983 tentang Pajak Penghasilan, (2009).

Sakina, S. M. (2017). Pelaksanaan Kewajiban Perpajakan Oleh Bendahara Desa Dalam Pengelolaan Dana Desa Ditinjau Dari Asas
Kepatuhan Di Kecamatan Berbah, Sleman. Universitas Gadjah Mada,

Sarstedt, M., Ringle, C. M., \& Hair, J. F. (2020). Partial Least Squares Structural Equation Modeling.

Slemrod, J., \& Yitzhaki, S. (2002). Tax avoidance, evasion, and administration. In Handbook of public economics (Vol. 3, pp. 14231470): Elsevier.

Solikhatun, I. (2016). Analisis Pengelolaan Dana Bantuan Operasional Sekolah (BOS)(Studi Pada SMK Negeri 1 Yogyakarta). Kajian Pendidikan Akuntansi Indonesia, 5(5).

Subandi, H., \& Fadhil, M. I. I. (2018). Analisis FaktorFaktor Yang Mempengaruhi Kepatuhan Pajak Bendahara Desa Di Kota Batu. Berkala Akuntansi dan Keuangan Indonesia, 3(1), 1-16.

Sugiyono. (2015). Metode Penelitian dan Pengembangan Pendekatan Kualitatif, Kuantitatif, dan R\&D. Metode Penelitian dan Pengembangan Pendekatan Kualitatif, Kuantitatif, dan R\&D, 130-130.

Sumarni, N. (2015). Analisis Pengelolaan Dana Bantuanoperasional Sekolah (Bos) di SMPN 6 Satap Rambah Samo. Jurnal Mahasiswa Prodi Manajemen Fakultas Ekonomi, 2(1).

Susmita, P. R., and Ni Luh Supadmi. (2016). Pengaruh Kualitas Pelayanan, Sanksi Perpajakan, Biaya Kepatuhan Pajak, Dan Penerapan E-Filing Pada Kepatuhan Wajib Pajak. E-Jurnal Akuntansi, 1239-1269.

SUYATRA, I. P. (Producer). (2018). Audit Dana BOS, BPK Temukan 9 Pelanggaran, Kerugian Negara Rp 1,15 M. Retrieved from https://baliexpress.jawapos.com/read/20 18/11/21/104609/audit-dana-bos-bpktemukan-9-pelanggaran-kerugian-negararp-115-m

Titman, S., \& Keown, A. J. (2018). Financial management: Principles and applications: Pearson Education, Inc.

Waldy, M. B., Fatiah, N., \& Rizani, F. (2020). EVALUASI AKUNTABILITAS DAN TRANSPARANSI DANA BANTUAN OPERASIONAL SEKOLAH (BOS)(STUDI KASUS PADA MADRASAH TSANAWIYAH LINGKUNGAN KEMENTERIAN AGAMA KOTA PALANGKARAYA, KALIMANTAN TENGAH.

WICAKSONO, P. (2018). PROSEDUR VERIFIKASI PAJAK PENGHASILAN FINAL ATAS PENGALIHAN HAK ATAS TANAH DAN ATAU BANUNAN DI KANTOR PELAYANAN PAJAK ...: dspace.uii.ac.id. 
Witono, B. (2008). Peranan Pengetahuan Pajak Pada Kepatuhan Wajib Pajak.

Wong, K. K.-K. (2019). Mastering Partial Least Squares Structural Equation Modeling
(PLS-SEM) with SmartPLS in 38 Hours: iUniverse. 